\title{
Use of a digital platform in the selection of socially significant projects (through the example of the lisp in the Yakutia)
}

\author{
L Ushnitskaya*, $A$ Feofanova \\ North-Eastern Federal University, 58, Belinsky ave., Yakutsk, 677000, Russia
}

\begin{abstract}
The relevance of the research issue is explained by the global transition to digital format. Under the conditions of digitalization of all spheres of life, it turned out to be necessary to conduct a digital dialogue between state executive authorities and population. The Republic of Sakha (Yakutia), being the leading region of the implementation and development of IT technologies in the Far East, has introduced the use of a digital platform to resolve local matters. The paper discusses the experience of the implementation of the Local Initiatives Support Program. The transformation of the program was studied, taking into account the specific features of the republic, the presence of the Arctic territories in it, as well as the use of a digital platform as a tool to improve the implementation of programs.
\end{abstract}

\section{Introduction}

Nowadays participatory budgeting is quite well developed and is presented by different initiatives depending on the needs of countries all over the world. One of these practices is the Local Initiatives Support Program (hereinafter referred to as LISP). LISP has been implemented in the Russian Federation since 2007. The variety of the implementation of LISP projects in the constituent entities of the Russian Federation is reasoned by not only to different management processes at all levels, but also by special factors in the territory of the implementation. As of the end of 2019, LISP was already being actively implemented in over 61 regions of the country. In the Republic of Sakha (Yakutia), LISP is one of the programs for solving socially important local problems.

During the implementation of this program the important social and institutional effects of a mediumterm nature are achieved as a result of the large-scale implementation in the territory of the Republic of Sakha (Yakutia) of public infrastructure development projects based on local initiatives in addition to the direct results in the form of the development of municipal infrastructure. These effects are as follows: the increase in social activity of the population, the decrease in dependent rate, the growth of mutual trust between the population and the authorities, etc. Despite these results, the republic does not cease to improve the practice of participatory budgeting.

\section{Materials and methods}

LISP is one of the initiatives of participatory budgeting. It is based on the concept of direct involvement of citizens in the solution of local issues and, in particular, in the decision on the choice of priority areas for spending part of budget funds at the municipal, regional or national level, as well as subsequent control over the implementation of these decisions.

\section{Results and discussion}

The Republic of Sakha (Yakutia) started the implementation of the LISP in 2017. In 2017, only 5 pilot territories - municipalities, which included urban and rural settlements that were part of the municipal districts: Verkhnevilyuisky, Churapchinsky, UstAldansky, Khangalassky settlements (districts) and the urban district "Zhatay" participated in the LISP. Since 2019, all 445 municipalities of the republic have been participating in the LISP.

The most significant factor for winning the tender selection of the LISP is the activity (number) of the population that was present at the meeting during the choice of a particular project. In total, 928 thousand people live on the territory of the republic of participating municipal organizations, 203 thousand people or $22 \%$ took part in preliminary discussions of projects for 2020, 86 thousand people or more than $9 \%$ of the total population took part in the final meetings. There is the increase in the dynamics of population activity over the years of the implementation of the LISP.

Table 1. The number of meetings in the municipalities of the Republic of Sakha (Yakutia) organized by the LISP for 20182020, thousand people

*Corresponding author: ulei50@mail.ru 


\begin{tabular}{|c|c|c|c|}
\hline Years & $\begin{array}{c}\text { Number of residents in } \\
\text { municipalities }\end{array}$ & $\begin{array}{c}\text { Participated in the preliminary } \\
\text { identification of the problem }\end{array}$ & $\begin{array}{c}\text { Took part in the final } \\
\text { meetings }\end{array}$ \\
\hline 2018 & 586 & 165 & 82 \\
\hline 2019 & 927 & 183 & 85 \\
\hline 2020 & 928 & 203 & 86 \\
\hline
\end{tabular}

The main result of the implementation of the participatory budgeting mechanism is the realization of the potential of citizens in the solution of specific socially significant tasks, which is confirmed by the activity and interest of the population, a change in the attitude of people to their own role in the development of territories, control by the population over the spending of program funds, the increase in the level of confidence in the actions of authorities in general.

Table 2. Information about the meetings and the projects for 2018-2020

\begin{tabular}{|c|c|c|c|}
\hline & 2018 & 2019 & 2020 \\
\hline Number of meetings & 528 & 627 & 551 \\
\hline Number of discussed projects & 1545 & 2225 & 1832 \\
\hline Number of projects submitted for tender & 503 & 565 & 503 \\
\hline Number of winning projects & 451 & 443 & 332 \\
\hline
\end{tabular}

If we talk about the Arctic territory of the republic, then we can confidently say that the residents of the Arctic territories are as much interested in the improvement of the territory as the residents of the central regions. Throughout the entire time of the implementation of the LISP on the territory of the republic, from the municipalities of the Republic of Sakha (Yakutia), which are part of the Arctic zone of the Russian Federation, 286 applications were submitted to tender (18\% of the total number of applications in the republic), including 94 in 2018 applications, 98 applications -in 2019, 94 applications - in 2020.

Due to the repeated appeals from the heads of municipalities to the regulatory legal act governing the procedure of tender selection and allocation of subsidy funds for the LISP, the particular changes were made regarding the creation of a separate window when conducting tender selection for municipalities of the Arctic regions. As practice shows, the municipalities of the Arctic regions can not compete on equal terms with the central regions, which is due to the low number of residents of settlements, the remoteness of territories from each other and special conditions for the timing and cost of the delivery of materials and high costs in the implementation of projects.

Earlier, by the Decree of the President of the Russian Federation V.V. Putin dated May 13, 2019 N 220 "On Amendments to the Decree of the President of the Russian Federation of May 2, 2014 N 296" on the Land Territories of the Arctic Zone of the Russian Federation additional 8 regions of Yakutia were included. Thus, all northern regions of the republic are now classified as arctic.

The additional window for arctic regions will help to increase the number of participants, the number of winners among the municipalities of the arctic regions and the elimination of competition with the rest of the regions. Thus, the projects of the municipalities of the Arctic regions will compete on equal terms between similar projects.

In 2018, citizens usually gave preference to the projects on the arrangement of sports grounds, the next most important projects were related to the organization of water supply and landscaping. In 2019, the share of projects aimed to improve water and heat supply facilities increased, followed by projects on the arrangement of sports grounds. In 2020, the first was the share of projects related to the improvement of places of residence and aimed at the improvement of territories (these are the places of public entertainment, landscaping of parks and squares, adjacent territories, arrangement of sidewalks, landscaping of burial sites, lighting projects, etc.). The second was the share of water and heat supply facilities. The activity of the population of the Arctic regions is presented in Table 2.

Table 3. The number of meetings of the municipalities of the Arctic regions of the Republic of Sakha (Yakutia) according organized by the LISP for 2018-2020

\begin{tabular}{|c|c|c|c|}
\hline Years & $\begin{array}{c}\text { The number of residents living in } \\
\text { the municipalities of Arctic } \\
\text { regions }\end{array}$ & $\begin{array}{c}\text { The number of residents who took } \\
\text { part in the preliminary } \\
\text { identification of the problem }\end{array}$ & $\begin{array}{c}\text { The number of } \\
\text { residents who took } \\
\text { part in the final } \\
\text { meetings }\end{array}$ \\
\hline 2018 & 67583 & 15529 & 9262 \\
\hline 2019 & 67674 & 26006 & 10166 \\
\hline 2020 & 67625 & 25847 & 12958 \\
\hline
\end{tabular}

In general, we can note the increased interest in the project on the part of the population and municipalities and participation in in it. The achieved results, as well as the fairly high quality of documents prepared directly in municipal settlements, indicate the ability and readiness of the municipalities of the Republic of 
Sakha (Yakutia) and the population to implement larger-scale projects related to the participation of the population.

The amount of subsidies from the State budget of the Republic of Sakha (Yakutia) for co-financing projects for the development of public infrastructure based on local initiatives is 500.0 million rubles annually. The figures show that co-financing for the project from all sources is increasing every year by an average of $27.5 \%$. This indicator also shows the high interest of the population of the republic in the development of the place of residence and the improvement of public spaces. For each ruble of subsidies allocated from the state budget of the Republic of Sakha (Yakutia), an additional 37.2 kopecks of co-financing is attracted.

\section{8}

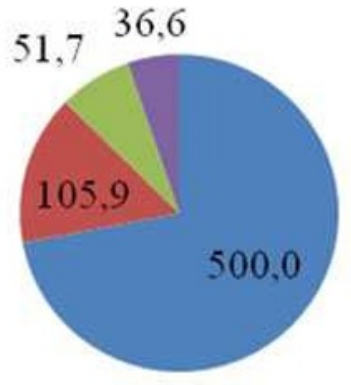

State budget of the

Republic of Sakha

(Yakutia)

Contribution

by local budget

= Contribution

by population

- Contribution

by sponsors

Figure 1. The ratio of state budget funds and additional co-financing for 2018 , million rubles

2019

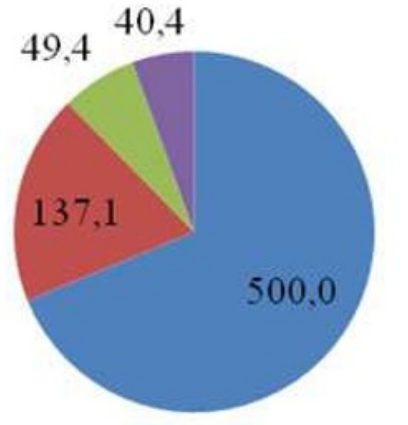

State budget of the

Republic of Sakha

(Yakutia)

Contribution

by local budget

- Contribution

by population

- Contribution

by sponsors

Figure 2. The ratio of state budget funds and additional co-financing for 2019, million rubles

2020

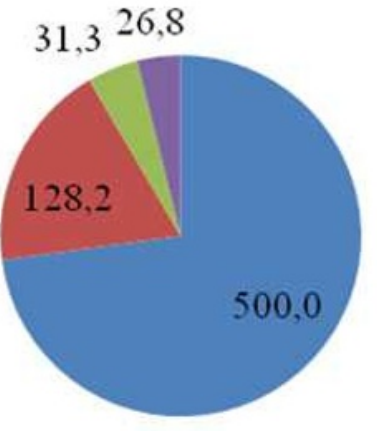

State budget of the

Republic of Sakha

(Yakutia)

Contribution

by local budget

Contribution

by population

Contribution

by sponsors

Figure 3. The ratio of state budget funds and additional co-financing for 2019, million rubles

(hereinafter referred to as $\mathrm{HaV}$ ), which united all programs with the initiative of citizens. The project included republican programs implemented on the

Starting from 2020, the LISP became a part of the republican project "Hometowns and Village" principles of the support of the initiatives of citizens, such as: the Program for Supporting Local Initiatives, 
the All-Republican Movement of Good Deeds "My Yakutia in the $21^{\text {st }}$ Century", the Regional Project "Formation of a Comfortable Urban Environment" and Integrated Development of Rural Areas of the Republic of Sakha (Yakutia). The project was established in accordance with the instructions of the Head of the Republic of Sakha (Yakutia) A.S. Nikolaev.

The purpose of the $\mathrm{HaV}$ is to enhance the participation of the residents of the Republic of Sakha (Yakutia) in the solution of local problems, the availability and ease of the participation of the republic population in the selection of projects to create comfortable living conditions for them and to increase the social and civic activity of citizens.

The tasks of the HaV are:

- The increase in the income and employment of the population;

- The increase in the efficiency of spending budget funds;

- The intensification of the interaction of local selfgovernment bodies of municipalities and the executive power and residents of the Republic of Sakha (Yakutia);

- The increase in the level of information transparency in the activities of local self-government bodies of municipalities and the executive power of the Republic of Sakha (Yakutia);

- The improvement of the quality of the solution of local issues by local self-government bodies of the Republic of Sakha (Yakutia);

- The intensification of control by the population over the exercise of the powers of local selfgovernment bodies of municipalities and the executive power of the Republic of Sakha (Yakutia);

- The increase in public satisfaction with the quality of work of local self-government bodies of municipalities and the executive power of the Republic of Sakha (Yakutia).

For the optimization of work with the population within the framework of the $\mathrm{HaV}$, the following activities are carried out:

- Simultaneous organization of meetings of the population at the $1^{\text {st }}$ stage, at which projects will be selected;

- The introduction of an integrated information portal "OneClickYakutia", where any citizen of the republic can get full information about the implementation of a project on the territory of a particular municipality, as well as about the timing of voting and projects proposed for discussion;

- A general interdepartmental tender commission, which will carry out work on the consideration of projects based on the initiatives of citizens of the Republic of Sakha (Yakutia), chaired by the First Deputy Chairman of the Government of the Republic of Sakha (Yakutia).

The implementation of the $\mathrm{HaV}$ consists of 4 stages:

- Stage 1 is preparatory and it includes: training of the representatives of municipalities, organization of meetings with the public, distribution of information on the acceptance of tender documents;
- Stage 2 is tender selection of projects, it includes: the formation of tender applications, their submission on the site "OneClickYakutia", work with tender documents, preparation of materials for the meeting of the interdepartmental commission and the tender selection of projects;

- Stage 3 is the allocation of funding, it includes: the work of chief administrators of budgetary funds on the preparation of the necessary regulatory legal acts and work with the Ministry of Defense to conclude agreements for financing projects;

- Stage 4 is the implementation of projects by the winners of the tender selection; it includes the organization of tender procedures for the selection of contractors, implementation of projects and submission of reports on implementation.

The main achievement of the $\mathrm{HaV}$ implementation was the introduction of an integrated information digital portal "OneClickYakutia". The largest digital module, the LISP program, has been fully transferred to the digital platform "OneClickYakutia".

According to the LISP, the selection of initiative projects for 2021 was online using the digital platform "OneClickYakutia" and social networks. Today, 182 ideas have been proposed by initiative groups on the OneClickYakutia digital platform. About 34,926 residents of the republic took part in online meetings. On the LISP website, 457 reports of the final meetings were uploaded, a total of 1974 projects were discussed, and 477 applications were created for the participation in tender selection.

\section{Conclusion}

As a result of the introduction of an integrated information portal "OneClickYakutia", any citizen of the republic can receive full information about the implementation of a project in the territory of a particular municipality, as well as about the timing of voting and projects proposed for discussion. It also provides a one-time acceptance of tender application using the digital platform "OneClickYakutia".

We can state that both the online project selection stage and the final voting stage were tested and proven in the pilot mode on the digital LISP module. The municipalities, including those of the Arctic regions organized meetings and final voting on an integrated digital platform 'OneClickYakutia". Therefore it gave the greatest effect in the attraction of participants to the discussion on the choice of an initiative project. This innovation, in the form of digital voting, in the process of resolving issues of local importance, greatly facilitated and improved the implementation of initiative projects in the context of openness and accessibility of data for the population and the effective activity of the government.

This experience of the implementation of digital voting in the LISP within the framework of the $\mathrm{HaV}$ can be repeated and recommended to other programs implemented on the principles of the support of the 
initiatives of citizens, as well as at the level of other regions of the country.

\section{References}

1. Decree of the Head of the Republic of Sakha (Yakutia) No. 1542 "On the project Hometowns and villages", (2020)

2. Guidelines for the preparation and implementation of participatory budgeting in the Russian Federation of the Ministry of Finance of the Russian Federation, (2020)

3. Report of the Ministry of Finance of the Russian Federation on the best practices for the development of participatory budgeting in the constituent entities of the Russian Federation and municipalities (2020)

4. Integrated digital platform "OneClickYakutia”, module of the Program for Supporting Local Initiatives of the Republic of Sakha (Yakutia) Retrieved from: https://ppmi.yakutia.click

5. Vagin V.V., Pominov K.V.a, et al. 50 questions about participatory budgeting: a tutorial (Moscow: Filin, 2018) 